\title{
Calvin's view on church discipline and unity: a South African perspective
}

\author{
P.J. Strauss \\ Department of Ecclesiology \\ University of the Free State \\ BLOEMFONTEIN \\ E-mail: straussp.hum@ufs.ac.za
}

\section{Abstract \\ Calvin's view on church discipline and unity: a South African perspective}

The reformer John Calvin, born in 1509, considers discipline and unity as two essential aspects of the Christian church. According to him, the bond of church discipline is a way to unite church members in the truth of the Word and the Christian faith based thereupon.

If discipline is exercised with exaggerated strictness and without compassion, tolerance and love, it can break the unity. Because church unity is essentially a unity of faith, or a unity in the truth of the Word, discipline can sever adulterated elements that threaten the unity from the church. Discipline, if correctly applied, builds the unity of the church as a unity in religious truths.

\section{Opsomming}

Calvyn oor die kerklike tug en kerkeenheid: 'n Suid-Afrikaanse perspektief

Die hervormer, Johannes Calvyn, gebore in 1509, beskou tug en eenheid as twee noodsaaklike aspekte van die Christelike kerk. Volgens hom is die band van die kerklike tug 'n manier om kerklidmate te verenig in die waarheid van die Woord en die Christelike geloof wat daarop gebou is.

Indien die tug met 'n oordrewe strengheid en sonder barmhartigheid, verdraagsaamheid en liefde uitgeoefen word, kan dit die eenheid verbreek. Omdat kerkeenheid in sy wese geloofseenheid of 'n eenheid in die waarhede van die Woord is, kan die tug onsuiwere elemente wat die eenheid bedreig van die 
kerk afsny. Tug wat reg toegepas word, bou die eenheid van die kerk as 'n eenheid in geloofswaarhede.

\section{Introduction}

There is a lively perception that the well-known reformer of Geneva, John Calvin (1509-1564), the spiritual father of so-called Calvinism, was strict and almost heartless in his application of church discipline, and that Calvin had no room in the church for people who parted from him in their views on church doctrine and the Christian life (Kuiper, 1995:194-195).

From this angle it seems contradictory that Calvin should see an ally for church unity in church discipline.

Some questions arise: What were Calvin's views on church discipline and how could he see in this a supporter of true church unity? And, what are the core elements of Calvin's view on true church unity? - a unity that should also reflect the nature of the church.

With this in mind, this article concentrates of Calvin's view on church discipline as being a spiritual administration of justice and, in doing so, building the unity of the church. These topics are looked upon against a broader view of Calvin on discipline and some positive reflections from the reformed tradition in South Africa.

\section{Calvin on discipline}

John Calvin used the conventional Latin word for discipline, disciplina, in its various meanings. To him this word can mean: an ordered Christian life, order or the sound course of issues in the church, and church order. Under the latter two themes he also places in the same class admonishing or reprimanding behaviour or church discipline.

Calvin links church discipline to morum disciplina, or discipline concerning life and the so-called disciplina excommunicationis, or discipline that refers to banning or excommunication. Under morum disciplina or life discipline he also places doctrinal discipline in the same category (Calvijn, s.a.:4.193; cf. Plomp, 1969:76). Calvin believes that life and the body of Christians must be disciplined. Thus, both church and state can as institutions help with this (Calvijn, s.a.:

3.71 ff.; 4.256; Plomp, 1969:62). 
According to Calvin, man in this life is subject to two authorities. One is the spiritual authority that trains human conscience in the service of God. The other is the civil authority that teaches man civil duties towards fellow human beings. The former is directed to the inner human being, while the latter is aimed at his morals. Man is subject to both the gospel and human laws (Calvijn, s.a.:3.374 ff.).

Plomp refers to Weber who alleges that Calvin implies the same terminology for the relationship between church and state as the Council of Chalcedon used in 451 for the relationship between the Divine and the human nature of Christ: undivided, unseparated, unmixed and unchanged (Plomp, 1969:128; cf. Kuiper, 1995:33). These formulations are indeed acceptable if this wording on it's own - not within the context of a sound Christology - is applied to the relation church and state.

Calvin views the church as the soul and the state as the body of human society. The former concerns the future life and the spiritual kingdom of Christ (Calvijn, s.a.:4.555-556). The latter is an institution of God after the fall of man; it operates, like the church, with divine authority and acts to a certain extent as a substitute for God on earth (Calvin, 1947:477-479; Calvijn, s.a.:4.559). ${ }^{1}$

Calvin believes that civil authorities must act reasonably towards all those over whom they rule. The laws of various government authorities can differ according to their country's conditions. Fairness must, however, be the aim and limitation of all state laws (Calvijn, s.a.:4.576).

Calvin alleges that the government authority is in the execution of its task also obliged to apply both tables of God's law (Calvijn, s.a.: 4.566). Therefore, in its judicial duty, it must protect both the Christian church and religion, and defend the healthy doctrine (Calvijn, s.a.:4.557). With this conviction the reformer of Geneva goes directly against the present religious-neutral constitution of the Republic of South Africa (Kleyn \& Viljoen, 1999:268) and the broadly accepted view among the reformed in this country that the government,

1 As God's procurators or servants of divine justice, the rulers of the state must, according to Calvin, see to it that their subjects consider them an image of God's providence, custody, goodness and justice. They fulfil a holy duty and any trespassing on their part is unfair towards their subjects and an insult to God (Calvijn, s.a.:4.562). In South Africa, with its daily news of poor service and corruption by people in the service of the state, Calvin's statement is of course contemporary and, therefore, extremely necessary and applicable. 
instead of the church, cannot in legal terms promote Christian faith. 2 Such action requires the Word as spiritual means in the hands of the church and does not come from the enforcing authority of the state.

The present constitutional state in South Africa is historically and fundamentally far removed from Calvin's sixteenth-century Geneva. Calvin views the Geneva of his time as a theocratic Covenant society - a Christian community of baptised human beings who are within the church and the (city) state directly subject to the authority of God and his Word (Pont, 1986:36, 37, 41).

The spiritual authority of the church is distinct, but not separated from the state in legal terms. A spiritual authority which, according to Calvin, must deliver geestelijke rechtspraak. The church cannot do without this (Calvijn, s.a.:4.241; cf. Sadler, 1979:1).

To Calvin church authority comes from and through the Word of God. In its control of human sin and disobedience in the licht van de Schrift (Plomp, 1969:72), this spiritual authority does not make the civil government superfluous. On the contrary, the spiritual Wordbound authority of the church helps and strengthens civil authority (Calvijn, s.a.:4.235-238).

\section{Calvin on the nature and purpose of church discipline}

According to Calvin, church councils were appointed from the outset to apply censure, punish sins and administer authority. Paul calls these authorities or predecessors which were added to the church or the parishes not government authorities, but shepherds caring for the flock (Rom. 12:8; 1 Cor. 12:28). In his letter to Timothy, Paul mentions two kinds of elders: those who serve the Word and those who do not preach, but rule (Calvijn, s.a.:4.235).

Christ let the latter supervise the morals of church members or gave them the extended authority of the church. As the ultimate key power, the extended power also lies in the preaching of the Word, but in a different manner. This is linked to preaching, but is given in the Name of the Lord and following a whole-hearted or lack of

2 Cf. in this instance the international debate on article 36 of the Belgic Confession of Faith which has, for example, led to an amendment of this section in the Dutch Reformed Church. This amendment implies that the government cannot directly promote a specific church, à la Calvin, but provides the legal framework within which churches can act in religious freedom (Polman, s.a.:290 ff.). 
remorse by the sinner - in concrete cases to forgive or keep sins and thus to bind or dissolve man's redemption on earth in heaven. According to Calvin, Matthew 16 and John 20 reveal the key power when Jesus Christ gives Peter and his disciples the Word so that by preaching the Word they can be instrumental in ensuring man's holy redemption on earth and in heaven (Calvijn, s.a.:4.236, 240). The main content of the Word or gospel is redemption for those who believe in Christ and condemnation for those who reject Him as Saviour and Redeemer. When Christ in Matthew 16 implicates this on preaching, He implicates this on discipline in Matthew 18 (Plomp, 1969:75). In both instances, it concerns key power with eternal consequences for the salvation of man (Calvijn, s.a.:4.238).

According to Calvin, no community of people, even the family, can exist without discipline. This also applies to an orderly church. While the redeeming doctrine or message of Christ is the soul of the church, discipline is the muscle or nerve that unites the members of this body. Those who ignore church discipline, on purpose or without thinking, destroy the church.

Nobody may do what she/he wants in the church of Jesus Christ. Discipline encourages and leads people who are against the doctrine of salvation in Christ or who are merely lazy. Often the fatherly rod disciplines those who have seriously sinned, with the gentleness of Christ (Calvijn, s.a.:4.257). ${ }^{3}$

With his conviction that church authority and discipline are spiritual by nature, Calvin finds wide following among the reformed on the purpose of discipline. 4 Sadler is of the opinion that in this instance he is "unequivocally" followed by authors of the reformed church law. Although Calvin does not systematically approach, but only at one point deals with this in his Institution, it does reveal what he considers as the purpose of church discipline.

3 Section 57 of the Church Ordinance of the Dutch Reformed Church in 1962 (General synod) provides that those who practise church discipline must not consider themselves judges, but paternal keepers. Unlike the point of view that these words refer to the Dordt Church Ordinance of 1619 and Calvin, Sadler (1979:8) shows that it originates almost verbatim from the Dutch General Regulation of 1816 with its collegial undertone.

$4 \quad$ Besides church ordinances, e.g. Van der Linde (1983:229); Visser (1999:261); Engelhard and Hofman (2001:433); NGK (2007:24); cf. also individual authors such as Jansen (1913:188 ff.); Greyvensteyn (1973:73 ff.); Sadler (1979:15) and Visser (s.a.:50). 
To Calvin, the sinner must show repentance or remorse (Calvijn, s.a.:4.240). Those who are known for leading a scandalous life may not be called Christians as this will insult the Lord: as if his holy church is a samenrotting van boze en misdadige mensen. A scandalous life is a rejection of the purpose of Holy Communion so that those who do it desecrate the sacrament (Calvijn, s.a.:4.260). The sinner must repent and the bad example must be removed to prevent the parish from being infected and the Name of Christ from being slandered (Calvijn, s.a.:4.265).

Calvin uses Augustine's battle with the Donatists as an example when he argues that a church that applies discipline is not perfect. The Donatists, who labelled the church as an institution of perfect people, considered the bishops who punished sins in the church with words and not with excommunication, as traitors of discipline. Therefore they were cut off from the church.

By contrast Calvin takes up a more moderate position. He supports Augustine's argument that Scripture instructs us to rule out with moderate care the fouten der broeders by maintaining pure love and protecting the unity of peace. The Donatists view this moderation, however, as a weakness and an opportunity to split and break down the church. Thus, Satan changes into an angel of light who severs the bond of unity and peace (Calvijn, s.a.:4.268-269).

Calvin's views on the purpose of church discipline has since been accepted in many reformed churches and worded in the famous tripartite aim of discipline. Consequently the purpose of church discipline is described as spiritual discipline directed at the honour of God, the welfare of the church and the keeping of the sinner (NGK, 2007:24; Sadler, 1979:15; Visser, s.a.:50 ff.).

\section{Calvin and the spiritual administration of justice}

In the light of Calvin's use of the terms spiritual authority, spiritual administration of justice and shepherds of the flock, reformers have, from a South African perspective, recently worked out two generally accepted consequences.

Firstly, that responsible (Bible-based) church discipline as a spiritual administration of justice also has legal (or in legal terms: quasijudicial) aspects. According to Du Plooy (2007:18 ff.) these aspects imply fairness in the discipline inquiry and respect for the so-called rules or principles of natural justice. Sadler (1979:51) alleges that these rules or principles not only originate from general considera- 
tions of fairness, but also correspond with the principles of Scripture. On this point Du Plooy (Reformed Churches of South Africa) and Sadler (Dutch Reformed Church), both acknowledged church politicians, agree with one another.

In addition, a disregard of the rules of natural justice forms one of two grounds which South African courts considered in the past before revising or disregarding church discipline findings from outside. Sadler refers to the rules of audi alteram partem, nemo iudex in causa sua, impartiality and attention paying. Briefly: the rule that one should also listen to the other side, that nobody may act as a judge in his/her own affairs, that a church meeting which investigates the matter must act impartially, and that the severity of the case should suit the attention paid to it. In the South African context, the church order of the Dutch Reformed Church (NGK, 2007:24) tries to obviate this ground for the revision of a church pronouncement by the civil court by providing that church discipline must also be applied "fairly and justly" from a biblical and spiritual point of view.

The other ground for revision used by the South African courts was whether the relevant church remained true to its own internal provisions or church order (Sadler, 1979:182-192). The test applied for this is not whether the court can interpret the relevant church's own church order better than the relevant church itself, but whether the church, according to canonical experts, did not interpret its own order so obviously wrongly that it indicated male fide (Sadler, 1979:177-179). South African courts find it permissible to apply the test whether the relevant church members do not interpret a matter of, possible, false doctrine so wrongly that it points to a wrong motive or male fide (Sadler, 1979:178).

The second consequence of Calvin's spiritual addressing of church discipline lies in the typifying of its nature in the recent past. The approach of the Dutch Reformed Church probably forms the climax of this in the South African context. With reference to Paul's symbol of the shepherd, as quoted by Calvin, section 60 of the Dutch Reformed Church Order, describes the official church supervision and discipline as pastoral-canoncial by nature. 5 The argument in his context is probably that the rules of natural justice fulfil an essential

5 Cf. Zeeman (s.a.). This author from the Dutch Reformed Church links church discipline directly to the elders as shepherds of the flock. 
service in church discipline cases which, according to this church order, must be biblical-ethical and pastoral by nature and thus also fair (Strauss, 2008a:107). 6 In it's church order the Reformed Churches of South Africa stress the conviction that church discipline is also spiritual and should reconcile people with their neighbours. Nothing is mentioned here of the rules of natural justice, although the church order and Du Plooy do not necessarily oppose each other on this point (Van der Linde, 1983:229; Visser, 1999:261).

The gist of the argument against Rudolph Sohm's (1923:22, $26 \mathrm{ff}$.) thesis that the law is in conflict with the nature of the church was already noted by Calvin concerning church discipline. With his spiritual administration of justice Calvin shows that spirituality and justice do not exclude each other, but that a scripture-based spirituality must still be fair and employ the principle of justice, when necessary. Calvin was apparently aware of the reformatory insight that everything in God's creation is connected to everything (Fowler, 1988:28).

In addition, following in the footsteps of the church fathers Cyprian, Chrysostom and Augustine, Calvin is convinced that church discipline must be associated with gentleness and fairness. 7 The aim of discipline must continuously be borne in mind, namely that the sinner repents and the bad example be removed from the parish so as not to infect the parish and slander the Name of Christ. If the sinner repents, she/he should no longer be punished. In this instance, discipline has achieved its goal. In this respect the old church has deviated, with its excessive strictness, from the prescription of Christ. Hypocrisy or despair can follow a yearlong or lifelong withholding of someone from the Holy Communion. This is not helpful and it is unfair when a person who has sinned for a second time is no longer allowed to do penance and is banned from the church (Calvijn, s.a.:4.264-265).

$6 \quad$ Van 't Spijker (1991:148) justifiably comes to the conclusion that Calvin did not regard church discipline as something judicial, but rather as something pastoral. In this regard Calvin followed Martin Bucer.

$7 \quad$ Sadler (1979:13-14) quotes Plomp (1969:76) with approval who alleges that Calvin (Calvijn, s.a.:4.264-269) wanted to apply discipline with an "evangelic intention". According to him, discipline must be applied carefully - too much leniency is not suitable - but on the other hand also with mildness, friendliness and compassion. 
Visser (s.a.:64) interprets this rightly that Calvin is of the opinion that it is arrogant of the church to think that excommunication throws one in eternal death and damnation. No person can pronounce the final judgement. This rests with God (cf. Plomp, 1969:106-108).

The accusation that Calvin was extraordinary strict on people with different views on matters of doctrine, does not take into account that Calvin applied his general principles for church discipline to all such cases. For him it was a matter of severe stress to discipline people (heretics) like Bolsec and Servet - disciplinary cases which were not his responsibility alone and in which he did not always had his own way (Van der Walt, 2009:292, 297). Nauta (1965:129) refers to a comment by Calvin in a letter to Farel in 1538 in which he laments that people which one would rather like to see banned, should be tolerated in church. As Parker (2002:131) explains it:

[for Calvin the church is not] ... merely a group of people sharing the same outlook, the same ideas, the same purposes, not even a body of people with a common faith, hope and love. The Church is the body united with its Head. It is Christ and his people as a unit. Hence it is the presence of Christ as the Head of the body that makes the body into the Church ...

... and his presence is realized in the earthly forms of the Gospel and the sacraments.

For Calvin excommunication is placing the unrepentant sinner outside communion with his fellow members and with Christ. Parker (2002:145), however, also stresses the point that for Calvin it was clear from Scripture that some form of discipline was not merely desirable but necessary. A sound church discipline is closely related to preaching and, indeed, a "subjunct" of it.

As Bratt (1973:141) puts it: "Calvin's toleration toward persons was unlimited, unless he was convinced that those persons were firmly committed to making propaganda for error." And "[e]ven when a man persists in what is actually erroneous conduct, we (the church) must deal patiently with him" (Bratt, 1973:148).

\section{Calvin: who disciplines, who is worthy of discipline and disciplinary steps}

Calvin instructs lawful church meetings to apply official church discipline. The spiritual key power must be separated from the sword power of the state and be practised in accordance with the discretion of only one person. The bishops of the early church did 
not exercise their power by means of punishments or prison sentences, but by means of the Word of the Lord alone: the sola Scriptura. According to this, the most severe church punishment is exile which must only be used in extreme cases.

Calvin occasionally declares that only those who have received the Holy Spirit can apply church discipline. Nobody can handle discipline in a biblical manner if she/he is not under the leadership and supremacy of the Word and the Spirit (Calvijn, s.a.:3.132; Plomp, 1969: 81).

For the church the primary means of discipline remains the Word. The Word must be used as a spiritual means of power to admonish and withhold someone from the Holy Communion (Calvijn, s.a.:4. 235; Plomp, 1969:73, 75, 81). Calvin pleads for generosity and mildness in discipline cases because he views discipline as a spiritual punishment (Calvijn, s.a.:4.235 ff.). He is also convinced that discipline serves as a spiritual remedy (Calvijn, s.a.:4.256 ff.).

It is known that Calvin is content with the pure preaching of the Word and the sacraments as the two characteristics of the true church or the so-called notae ecclesiae. Calvin's followers explicitly added discipline as a third characteristic.

Plomp (1969:124-125) concludes that Calvin ignores discipline as a third characteristic because he fears that this can replace the attention of the doctrina as foundation of the church with the people's loyalty to the disciplinary processes of the church. Calvin wants to give this honour only to the holy Word and the holy sacraments of the holy God.

As far as sins worthy of discipline or sins that must be dealt with by church meetings are concerned, Calvin distinguishes between secret and public sins. He associates secret sins with Matthew 18:15: "When your brother sins against you ...". The words "against you" mean according to Calvin "with your knowledge". Others do not yet know about this. In this instance, according to Calvin, Christ's instruction to "punish him between you and him alone" applies. If he does not want to hear about it, you take him to the church (Calvijn, s.a.:4.258-259).

Calvin also distinguishes between offences and crimes. An admonition can suffice for the former, but the latter must be dealt with more strictly. Calvin regards banishment as the punishment meeted out by 
Paul in a serious case (1 Cor. 5:4), as a normative example of this (Calvijn, s.a.:4.259).

In the light of Matthew 18, Calvin views the steps of church discipline as follows: first, a personal admonition, then an admonition before witnesses, and then an appearance before a meeting of elders. If there is no penance or repentance, such a person is considered a despiser of the church and must be cut off from the community of the faithful.

Each one of us must admonish his/her brother if necessary and each one of us who behaves unbecomingly must be admonished. This is, however, also the specific task or instruction of the shepherds and the elders (Calvijn, s.a.:4.257-258; cf. Zeeman, s.a.:6). Calvin distinguishes between general church discipline to which all members of the church are subject and discipline of those who are in a specific duty or service. As far as the latter are concerned, their specific services or tasks, or the termination thereof, must also be considered (Calvijn, s.a.:4.256).

For Calvin it is certain that discipline forms part of the church and, therefore, of the task of each faithful member of the church. His opinion that discipline is not one of the signs of the true church or notae ecclesiae does not prejudice his view that discipline is the nerve of the church which, according to him, directly affects the unity of the church.

The question regularly arises among South African reformed people whether discipline is truly treated on its merits - when the relevant church recognises this as sign of the true church. Except for a lack of knowledge among church assemblies, the exercise of church discipline is also limited by doubts about church authority as an authority of Christ (Strauss, 2008b:242-243). The result is that Calvin's use of the Scripture instruction to church members to admonish and to be admonished is ignored.

\section{Calvin, church discipline and church unity}

As far as the link between church discipline and church unity is concerned, Calvin uses the image of discipline as the muscles or nerve of the church that unite its members. According to Calvin, discipline must deal directly with church unity.

Plomp notes that Calvin's point of view that moderation and mildness must form part of the way in which church discipline is exer- 
cised, draws attention to the peace and unity of the church. Discipline must be attuned to protecting the unity of the Spirit and the bond of peace in the church. If this bond is not protected, the punishment of discipline is redundant and iniquitous (Calvijn, s.a.: $4.256 \mathrm{ff}$.$) .$

In this respect Calvin quotes Augustine with consent when he advises that the church must punish with compassion what he can punish, must patiently bear what it cannot punish and sigh and complain about this in love until God punishes, improves it or eradicates the weed. In particular, when part of the community is infected with sin, moderate strictness by means of compassion is necessary. A sin by a significant number of church members cannot be removed among the faithful strongly and hard. Such a consequence is reached by means of teaching and admonition (Calvijn, s.a.:4.26 ff.).

Calvin is clearly of the opinion that discipline, as imbedded in obedience to the Word, forms a bond that promotes the unity of the church. Discipline that promotes obedience to the Word is the best bond of unity which the church can have. Any Word-bound discipline that results in cutting off a person or persons, occurs in the Name of and on the authority of the Lord. This strengthens the unity of faith among those who remain behind. Obedience to the Word occurs on the authority of God and the unity among the faithful in this obedience and therefore also in its details, builds on the authority of God. The result is unity among the faithful in the truth of the Word and is a unity willed by God (Calvijn, s.a.:4.259).

With reference to this biblical line of unity Calvin alleges that the unity of the Spirit be respected when the faithful live in peace with one another and tolerate each other. This is linked to the realisation that the shortfalls in the church must be eliminated in the light of the Word by mutual admonition. A disapproval of sins must, however, be associated with caution and compassion so that the wheat is not removed with the weed (Calvijn, s.a.:4.267-268).

From a South African perspective it is clear that church unity, according to Calvin, does not depend on cheap church politics or is only possible through compentent negotiations. It is not a unity that bypasses church shortfalls or discipline differences as if it does not exist or is not important. It is a unity that arises from the work of unity of the Word and the Spirit of God.

It is a unity that later becomes recognisable in the reformed expression that the confessions of the church are the agreement of the 
church community or church unity (Bouwman, 1985:556). For Calvin church unity is first and foremost a unity in the Word and therefore probably, noting its argument for tolerance, a unity in the truth of the Word. Key truths are expressed in the confessions of the church (Jonker, 1994:6). Calvin is also convinced of fewer and more important and more serious matters in the church.

\section{Conclusion}

For the sixteenth-century reformer John Calvin the Word of God or the principle of sola Scriptura is foremost in church discipline and unity. In the principle of the sola Scriptura lies the unity between discipline and the unity of the church.

The respect of both in their respective association boils down for Calvin to obedience to God and his Word. According to him, sound church discipline and sound church unity must both build on God's Word.

\section{List of references}

BOUWMAN, H. 1985. Gereformeerd kerkrecht. DI. 2. Kampen: Kok.

BRATT, J.H. 1973. The heritage of John Calvin. Grand Rapids: Eerdmans.

CALVIN, J. 1947 [1539]. Commentaries on the epistle of Paul the apostle to the Romans. Trans. by J. Owen. Grand Rapids: Eerdmans.

CALVIJN, J. s.a. Institutie 3 en 4. Vert. door A. Sizoo. Delft: Meinema.

DU PLOOY, A. LE R. 2007. Beginsels vir regspraak in die kerk. Die Kerkblad:18-20, Apr.

ENGELHARD, D.H. \& HOFMAN, L.J. 2001. Manual of Christian reformed church government. Grand Rapids: CRC Publications.

FOWLER, S. 1988. The state in the light of the Scriptures. Potchefstroom: PU for CHE.

GREYVENSTEIN, J. 1973. Die kerklike tug. Pretoria: University of Pretoria. (Unpublished.)

JANSEN, J. 1913. De kerkelijke tucht. Arnhem: Tamminga.

JONKER, W.D. 1994. Bevrydende waarheid. Wellington: Hugenote-Uitgewers.

KLEYN, D. \& VILJOEN, F. 1999. Beginnersgids vir regstudente. 2e dr. Kenwyn: Juta.

KUIPER, B.K. 1995. The church in history. Grand Rapids: Eerdmans.

NAUTA, D. 1965. Calvijn en zijn gemeente. (In Van Genderen, J., red. Zicht op Calvijn. Amsterdam: Buijten \& Schipperheijn. p. 103-141.)

NEDERDUITSE GEREFORMEERDE KERK. 2007. Die Kerkorde. Wellington: NGK Bybelmedia.

see NEDERDUITSE GEREFORMEERDE KERK

PARKER, T.H.L. 2002. John Calvin. 2nd ed. London: Continuum.

PLOMP, J. 1969. De kerkelijke tucht bij Calvijn. Kampen: Kok.

POLMAN, A.D.R. s.a. Onze Nederlandsche geloofsbelijdenis. Franeker: Wever. 
PONT, A.D. 1986. Verbond en volkskerk. Hervormde teologiese studies, 42(1): 28-76.

SADLER, T.H.N. 1979. Die kerklike tughandeling. Pretoria: NG Kerkboekhandel.

SOHM, R. 1923. Das Kirchenrecht. TI. 1. Leipzig: Von Dancker \& Humbolt.

STRAUSS, P.J. 2008a. Die kerkorde van die Ned Geref Kerk: uitgangspunte ten opsigte van Skrif, belydenis en kerkorde. Acta theologica, 28(2):104117.

STRAUSS, P.J. 2008b. Die "kerklike gesag" van kerkvergaderings soos in die Kerkorde van die Nederduitse Gereformeerde Kerk. In die Skriflig, 42(2):239-252.

VAN DER LINDE, G.P.L. 1983. Die kerkorde. Potchefstroom: Potchefstroomse Teologiese Publikasies.

VAN DER WALT, J. 2009. Johannes Calvyn. Potchefstroom: Calvyn Jubileumboekefonds.

VAN 'T SPIJKER, W. 1991. Geest, Woord en kerk. Kampen: Kok.

VISSER, J. s.a. Kerklike tug. Pretoria: Van Wyk.

VISSER, J. 1999. Die kerkorde in praktyk. Orkney: EFJS.

ZEEMAN, M.T.S. s.a. Herders van die kudde. Bloemfontein: NG Sendingpers.

\section{Key concepts:}

church discipline: justice

church discipline: pastoral and spiritual in nature

unity: not uniformity

unity of the church: a unity in Christ

\section{Kernbegrippe:}

eenheid: nie eendersheid

kerkeenheid: geloofseenheid in Christus

kerklike tug: geregtigheid

kerklike tug: pastoraal en geestelik 